\title{
Intravascular radiation for restenosis prevention: could it be the holy grail?
}

The search for a solution to the most vexing problem facing coronary interventions continues. Restenosis after angioplasty was the major limitation of the technique when it was compared with coronary bypass surgery in recent trials. ${ }^{1}$

The concept of using endovascular radiation to prevent restenosis after angioplasty derives from the similarity between restenotic lesions and other types of wound healing phenomena. The current concept of restenosis is that the luminal renarrowing after angioplasty is the sum of early elastic recoil, neointimal formation, and late vascular constriction. The last two processes, the formation of new intraluminal tissue and the constriction of the vessel, are very similar to the scar formation and retraction that occurs during healing after injury of other tissues. The cells that form the neointimal lesion are believed to originate either from smooth muscle cells or fibroblasts or perhaps both. This process has been well characterised in the porcine coronary model of restenosis. ${ }^{23}$ In this model, disruption of vessel wall integrity is followed by migration, proliferation, and matrix formation which heals the disrupted artery. When this "healing" is excessive, the lumen is compromised.

Similar exhuberant healing responses are seen in the skin after traumatic or surgical incisions and in the sclera of the eye after pterygium removal. Such healing responses can be inhibited by the administration of ionising radiation shortly after surgical excision of the scars. If restenosis is akin to wound healing, similar attempts at localised radiation treatment seem feasible. Although previous treatments aimed at killing smooth muscle cells in the vessel wall-that is, the laser balloon-were ineffective, the observation of the action of radiation on cell culture gives a possible explanation for the different responses. In these studies, ${ }^{4-7}$ cells responded to radiation treatment by the process of apoptosis (programmed cell death) rather than necrosis. These cells lose their ability to replicate by virtue of changes in their DNA structure without the cell itself losing integrity.

\section{Experimental restenosis studies}

Studies using intravascular radiation have been performed in several models but the most compelling evidence comes from the porcine coronary balloon overstretch model..$^{8-10}$ These studies in general were carried out using gamma radiation (iridium-192). The effect at two weeks was quite dramatic with the formation of neointima being inhibited in a dose dependent manner ${ }^{10}$ (figure). Further observations of the effect of radiation have been extended to six months in the coronary arteries of mini swine. The dose dependent reduction in neointimal formation persisted

\section{Glossary}

STRESS $=$ Stent restenosis study

Benestent $=$ Belge Nederland stent beyond six months, suggesting a sustained effect. Importantly, late fibrotic changes, microvascular, and myocardial or pericardial damage were seen in the controls but not in the treated animals. ${ }^{8}$ This early experimental work was carried out with commercially available high dose rate afterloaders or iridium ribbons which could be hand delivered. These techniques are used in radiation oncology for cancer brachytherapy.

A more practical radiation source was sought to produce a system useful for coronary artery application. Beta radiation sources have been identified and catheters have been developed that can deliver such sources. ${ }^{11}{ }^{12}$ Because the beta radiation is absorbed within a few millimeters of tissue, this source is very safe, not only for the patient but also for the operators who no longer have to move away from the patient's side. The results obtained with one of these beta energy systems in the porcine coronary overstretch injury model were identical with those obtained with gamma radiation ${ }^{11}$ - as was the dose dependent suppression of the neointima formation.

\section{Clinical application}

Radiation oncology devices using gamma energy have
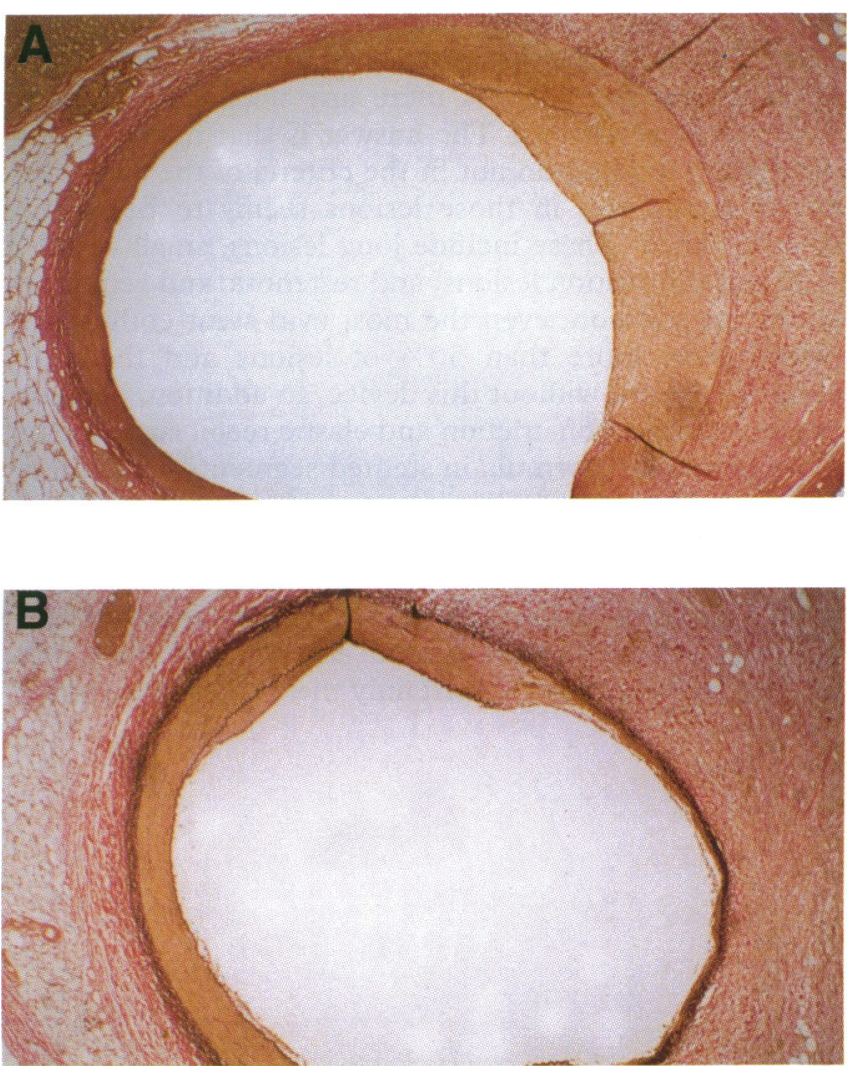

(A) Porcine coronary artery two weeks after balloon overstretch injury showing exhuberant proliferative response filling the crater created by the broken ends of the media. (B) Similar porcine coronary model two weeks after balloon overstretch injury with the application of endovascular radiation showing inhibition of the neointima formation between the broken ends of the media. 
been used in some patients over the past few years. The first clinical work was from the group in Frankfurt treating patients with previous restenosis in the femoral artery. Follow up clinical observations and non-invasive testing suggest sustained benefit. ${ }^{13}$ The gamma radiation source has also been used in coronary arteries in Venezuela and in San Diego. A major limitation of this approach is that the laboratory personnel must leave the patient for up to $30-40$ minutes required to deliver the prescribed radiation which is not blocked by the usual lead apron or other protection devices. This makes it impractical for interventional cardiology.

\section{A practical system}

Because the gamma radiation sources required the operator to leave the patient's side and required prolonged dwell times in the coronary artery, another more practical source was sought. A beta radiation source was identified and a catheter was developed which could deliver such a source. Because the beta radiation is absorbed within a few millimeters of tissue, this source became very safe, not only for the patient, but for the operators who no longer had to absent themselves from the patient's side. This system has now undergone extensive animal testing and human trials have begun at our centre.

Others have advocated a more sustained delivery of radiation using radioactive stents. ${ }^{14}{ }^{15}$ At present it appears that neointimal formation after stenting can be inhibited both by a sustained low dose radioactive stent and by onetime catheter based radiation at the time of stenting. ${ }^{14-16}$

\section{Implications}

The greatest change in interventional cardiology practice has come during the past two years with the broad application of coronary stenting. The STRESS and Benestent trials ${ }^{17} 18$ showed that the restenosis rate could be reduced by about one third. So is there any need for a further reduction in restenosis? The answer is that many lesions undergoing stenting do not fit the criteria of the trials and the restenosis rate in those lesions seems to be in the $30-40 \%$ range. These include long lesions, small vessels, ostial and bifurcation lesions, and restenotic and vein graft lesions. In addition, even the most avid stent enthusiasts seldom stent more than $50 \%$ of lesions and therefore many are treated without this device. In addition, because chronic vascular constriction and elastic recoil are not part of the lumen loss formula in stented segments, irradiation may provide a great opportunity to reduce the neointimal formation that remains the sole cause of late lumen loss in these patients. On the other hand, if endovascular radiation is effective following other coronary interventions such as balloon angioplasty and atherectomy, then will stenting be as necessary? Certainly these questions, which can only be speculated on now, have important implications for the industry of interventional cardiology as well as for patient care.

The search for the holy grail of restenosis prevention has now gone on for 18 years and it is premature to suggest that the search is over. There is now, however, a new and powerful tool available for investigation and we remain hopeful about the results.

Andreas Gruentzig Cardiovascular Center of

SPENCER B KING III

Emory University,

Emory University Hospital

1364 Clifton Road NE, Suite F606,

Atlanta, Georgia 30322, USA

1 Pocock SJ, Henderson RA, Rickards AF, Hampton JR, King SB III, Hamm CW, et al. Meta-analysis of randomised trials comparing coronary angioplasty with bypass surgery. Lancet 1995;346:1184-9.

2 Karas SP, Gravanis MB, Santoian EC, Robinson KA, Anderberg K, King SB III. Coronary intimal proliferation after balloon injury and stenting in swine: an animal model of restenosis. F Am Coll Cardiol 1992;20:467-74.

3 Scott NA, Cipolla GD, Ross CE, Dunn B, Martin F, Simonet L, et al. Potential role of the adventitia in vascular lesion formation after balloon overstretch injury of porcine coronary arteries. Circulation (in press)

4 Puck TT, Morkovin D, Marcus PI. Action of $x$-rays on mammalian cells, II: survival curves of cells from normal human tissues. $\mathcal{F}$ Exp Med 1957;106: $485-500$.

5 Sinclair WK. Cyclic $x$-ray response in mammalian cells in vitro. Radiat Res 1968;63:620-43.

6 Fischer-Dzoga K, Dimitrievich GS, Griem ML. Differential radio-sensitivity of aortic cells in vitro. Radiat Res 1984;99:536-46.

7 Hall EJ. Cell-survival curves. In: Hall EJ, ed. Radiobiology for the radiologist. Philadelphia, Pa: Lippincott; 1988;17-38.

8 Waksman R, Robinson KA, Crocker IR, Gravanis MB, Cipolla GD, King SB III. Endovascular low dose irradiation inhibits neointima formation after coronary artery balloon injury in swine: a possible role for radiation therapy in restenosis prevention. Circulation 1995;91:1533-9.

9 Wiedermann JG, Marboe C, Schwartz A, Amols H, Weinberger J. Intracoronary irradiation reduces restenosis after balloon angioplasty in a Intracoronary irradiation reduces restenosis after

10 Mazur W, Ali MN, Dabaghi SF, Cristead C, Abukhalil J, Paradise P, et al. High dose rate intracoronary radiation suppresses neointimal proliferation in the stented and ballooned model of porcine restenosis (abstract). tion in the stented and ballooned modition 1994;90(suppl I):I-652.
Circulat

11 Waksman R, Robinson KA, Crocker IR, Wang C, Gravanis MB, Cipolla $\mathrm{GD}$, et al. Intracoronary low dose beta irradiation inhibits neointima formation after coronary artery balloon injury in the swine restenosis model. Circulation 1995;92:3025-31.

12 Verin V, Popowski Y, Urban P, Belneger J, Redard M, Costa M, et al. Intraarterial beta irradiation prevents neointimal hyperplasia in hypercholesterolemic rabbit restenosis model (abstract). $F$ Am Coll Cardiol 1995;2A.

13 Liermann DD, Boettcher HD, Kollatch J, Schopol B, Strassman G, Strecker EP, et al. Prophylactic endovascular radiotherapy to prevent intimal hyperplasia after stent implantation in femoro-popliteal arteries. Cardiovasc Intervent Radiol 1994;17:12-6.

14 Fischell TA, Kharma BK, Fuschell DR, Loges PG, Coffey CW, Duggan $\mathrm{DM}$, et al. Low dose B-particle emission from stent wire results in complete, localized inhibition of smooth muscle cell proliferation. Circulation 1994;90:2956-63.

15 Hehrlein C, Zimmerman M, Metz J, Fehsenfeld P, von Hodenberg E. Radioactive stent implantation inhibits neointimal proliferation in nonatherosclerotic rabbits (abstract). Circulation 1993;88 (suppl I):I-65.

16 Waksman R, Robinson KA, Crocker IR, Gravanis MB, Palmer SJ, Wang C, et al. Intracoronary radiation before stent implantation inhibits neoin-
tima formation in stented porcine coronary arteries. Circulation 1995;92: 1383-6.

17 Fischman DL, Leon MB, Baim DS, Schatz RA, Savage MP, Penn I, et al for the Stent Restenosis Study Investigators. A randomized comparison of coronary-stent placement and balloon angioplasty in the treatment of coronary-stent placement and balloon angioplasty in the

18 Serruys PW, de Jaegere P, Kiemeneij F, Macaya C, Rutsch W, Heyndrickx G, et al for the Benestent Study Group. A comparison of balloon-expandable-stent implantation with balloon angioplasty in patients with coronary artery disease. $N$ Engl $₹$ Med 1994;331:489-95. 